\title{
Antimicrobial Activity of Methanolic and Aqueous Extract of Rhodomyrtus tomentosa Leaves against Staphylococcus aureus and Escherichia coli
}

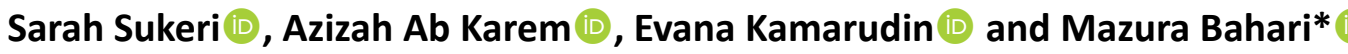 \\ Centre of Medical Laboratory Technology, Faculty of Health Sciences, Universiti Teknologi MARA, Selangor \\ branch, Puncak Alam Campus, 42300 Puncak Alam, Selangor, Malaysia.
}

\begin{abstract}
Food poisoning is one of the riskiest illnesses caused by an organism like bacteria, viruses and parasites, which can contaminate food at any stage of food production. Most reports are associated with bacterial contamination through the food preparation process. Researcher nowadays attempts to discover a safer agent to use in food preparation as a food preservative agent. Thus, the potential of Rhodomyrtus tomentosa leaves as an antimicrobial agent was explored in this study. It was tested against two bacteria which are Staphylococcus aureus (gram-positive) and Eschericia coli (gram-negative). Antimicrobial activity of methanol and aqueous $\boldsymbol{R}$. tomentosa leaves extract was compared using gram staining, bacterial identification, antimicrobial sensitivity testing (AST), minimal inhibitory concentration (MIC), minimal bactericidal concentration (MBC) and statistical analysis. The disc diffusion technique was used for AST where the mean area of inhibition methanol and aqueous extract against $S$. aureus was $18 \mathrm{~mm}$ and $16 \mathrm{~mm}$ respectively, whereas there was no area of inhibition for $E$. coli. MIC was done to determine the minimum concentration of the extract needed to inhibit the bacteria. After that, MBC was performed to confirm the previous MIC result. Statistical analysis was done by conduct it through SPSS software program. Then, the result for $S$. aureus is obtained from finding its $p$-value. Statistically, a significant difference between the two bacteria was analyzed by using independent $t$-test. A result of $\boldsymbol{p}$-value less than $\mathbf{0 . 0 5}$ was considered significantly different as one another. Statistical analysis showed no significant difference between methanol and aqueous extract on antimicrobial activity. In conclusion, both aqueous and methanol leaves $R$. tomentosa yielded similar antibacterial activity which susceptible to $S$. aureus and can be used safely toward foodborne pathogen.
\end{abstract}

Keywords: Food poisoning, antimicrobial, methanol extract, aqueous extract, Rhodomyrtus tomentosa

*Correspondence: mazura_bahari@yahoo.com; +6017 5477807

(Received: April 01, 2020; accepted: October 17, 2020)

Citation: Sukeri S, Ab Karem A, Kamarudin E, Bahari M. Antimicrobial Activity of Methanolic and Aqueous Extract of Rhodomyrtus tomentosa Leaves against Staphylococcus aureus and Escherichia coli. J Pure Appl Microbiol. 2021;15(1):186-193. doi:10.22207/ JPAM.15.1.13

(C) The Author(s) 2021. Open Access. This article is distributed under the terms of the Creative Commons Attribution 4.0 International License which permits unrestricted use, sharing, distribution, and reproduction in any medium, provided you give appropriate credit to the original author(s) and the source, provide a link to the Creative Commons license, and indicate if changes were made. 


\section{INTRODUCTION}

Food poisoning is one of the riskiest illnesses caused by an organism like bacteria, viruses and parasites, which can contaminate food at any stage of food production. Most reports are associated with bacterial contamination through the food preparation process. Researcher nowadays attempts to discover a safer agent to use in food preparation as a food preservative agent. Most of the food poisoning reports are as linked with bacterial contamination through the food preparation process ${ }^{1}$. Adding a synthetic antimicrobial agent to food as a preservative is one of the alternatives to suppress the microbial activity. Despite the proven efficiency, repeated usage of the synthetic antibiotics has resulted in the accumulation of chemical residues in food and food chain, acquisition of microbial resistance towards the applied synthetic antibiotics ${ }^{2}$. Over the last two decades of examples, bacterial infections caused by Salmonella enteritidis, Staphylococcus aureus, Escherichia coli and newer food borne pathogens have become increasingly resistant to empirical antimicrobial agents ${ }^{3}$.

Because of such concerns, efforts have been narrowed on developing potentially effective, safer and natural origin food preservatives. The utilization of plant extracts as antimicrobial agents in food preservation is much needed in these contexts. Plant extracts contain different bioactive compounds that play a key role in treating illnesses and even killing bacteria. The Malaysian rainforest is among the richest flora in the world where it encompasses several thousand species of vascular plants where it includes medicinal plant and herbs ${ }^{4}$. $R$. tomentosa, also known as rose myrtle or "kemunting" in Malay, is a flowering plant in the family Myrtaceae, is one of the medicinal plant identified to have an antimicrobial property due to its phytochemical properties. This species is native to tropical and subtropical from India, to southern China, Taiwan, Philippines, Malaysia and Sulawesi. According to Abdullah et al. ${ }^{4}$, information on genetic variation is a necessity to formulate an effective program and tomentosa is one of the genetic species other than parviflora who have known to have medicinal properties. Recently, the extract from the leaves of this plant has been demonstrated to exhibit susceptibility against a wide range of Gram- positive bacteria including, foodborne pathogens such as Bacillus cereus, Staphylococcus aureus, and Listeria monocytogenes at low minimum inhibitory concentrations ${ }^{5}$. The previous study also confirmed that, the extract of this plant also showed the ability to reduce both Bacillus cereus viable cells and endospores significantly when applied in tuna steak model and pre-cook rice ${ }^{6}$. The usage of $R$. tomentosa is not only specified in food preservatives. Historically, R. tomentosa has been used in traditional Vietnamese, Chinese, and Malaysian medicine to treat diarrhoea or dysentery, as well as stimulate the immune system ${ }^{7}$.

The present study was initiated to compare the effectiveness of antimicrobial properties in methanolic extract and aqueous extract of $R$. tomentosa against the selected organism, particularly gram-positive bacteria and gram-negative bacteria. The bacteria, namely Escherichia coli and Staphylococcus aureus are basically food-borne bacteria ${ }^{8}$. The previous study has been proven that the ethanolic extract of $R$. tomentosa possessed antimicrobial activity, but an aqueous extract of $R$. tomentosa does not. In the present study, the comparison was made between two solvent, which is methanol and aqueous solution to discover new finding, thus comparing with the previous study?

\section{MATERIALS AND METHODS Materials Media culture}

Media culture used for bacteria culture and identification are Nutrient agar, Tryptic Soy Broth, MacConkey agar, Blood agar, Eosin Methylene Blue agar, Triple Sugar Iron, Indole broth, Motility broth, Citrate agar, PD agar, DNase agar, Urease broth, Mueller Hinton broth and Methyl red-VP broth. For Antimicrobial Sensitivity testing, media culture used was Mueller Hinton agar and Mueller Hinton broth.

\section{Chemicals and reagent}

For bacteria confirmation, reagent used were Gram stain, normal saline, $3 \%$ hydrogen peroxide, $1 \%$ of tetramethyl-p-phenylenidiamine dihydrochloride, Kovac's reagent, Methyl red solution, $40 \% \mathrm{KOH}$ and plasma. In addition, for extraction purposes chemical used were absolute methanol and dimethyl sulfoxide (DMSO). 


\section{Bacteria culture}

There were 2 bacterial stock culture used in this study. They were obtained from the Microbiology laboratory, Medical Laboratory Department, Faculty of Health Science, UiTM Puncak Alam. The bacterial strains that were involved were Staphylococcus aureus and Escherichia coli.

\section{Instrument used in the lab}

For media preparation, the instrument that have been used were analytical balance (Precision), water purifier (Elga), stirring hot plate (Favorit), autoclave (Hiramaya), incubator (Friocell), chiller (Protech) and fume hood. Whilst, instruments that have been used for bacterial confirmation were incinerator, spectrophotometer (SmartSpec Plus Biorad), incubator (Friocell) and microscope (Zeiss). Lastly for plant extraction preparation, analytical balance, orbitary shaker, stirrer hot plate, rotay evaporator and freeze drier were used.

\section{Apparatus used in the lab}

Equipment that were used for media preparation were measuring cylinder, Schott bottle $(500 \mathrm{ml}$ and $2000 \mathrm{ml})$, magnetic stirrer bar, spatula, weighing boat, disposable petri dishes and bijou bottle ( $7 \mathrm{ml}$ and $14 \mathrm{ml})$. Next, for bacterial confirmation equipment used were wire loop, stab wire, sterile swab, disposable slides, toothpick, test tube and test tube with cap. Lastly, for extraction process, glass funnel, Schott bottle, beaker, Whatmann no 1 filter paper, spatula, weighing boat, aluminium foil, stirrer magnet tube, measuring cylinder, conical flask, conical tube and capped universal tube were used.

\section{Antibiotics}

Antibiotic used in this study were

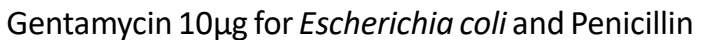
$10 \mu \mathrm{g}$ for Staphylococcus aureus. Both will act as positive control in Antimicrobial Sensitivity Testing.

\section{Methodology}

Collection and preparation of $R$. tomentosa leaves

The leaves of the plant were collected from Bukit Batu Putih Tanjung Tuan, Port Dickson, in Negeri Sembilan, Malaysia (GPS coordinates: $2.4113042,101.8470265)$. Verification of plant species was done at Forest Research Institute of Malaysia (FRIM). The collected plants were carefully selected for this study. Only fresh leaves were chosen. The leaves were washed and rinsed thoroughly. After that, they were all laid evenly and dried in the oven at a temperature of $40^{\circ} \mathrm{C}$ for 3 days. Lastly, the dried leaves were grounded in an electric blender until fine powdery substances are formed ${ }^{10}$.

\section{The extraction process of $R$. tomentosa}

For methanolic extract, the extraction was conducted using a 1:10 ratio w/v of $R$. tomentosa powder to absolute methanol. Hence, $31 \mathrm{~g}$ of powdered form of the plant was weighed and soaked into $310 \mathrm{ml}$ of methanol and kept in $500 \mathrm{ml}$ Schott bottle wrapped with aluminium foil. The solution was then mixed using a magnetic stirrer for 2 hours continuously. Next, the solution was filtered using Whatmann filter paper and glass funnel into a new Schott bottle. The filtered solution was then transferred into a conical flask and was concentrated using a rotary evaporator (Heidolph ThermoHaake K20) at $40^{\circ} \mathrm{C}$. The extract was then freeze-dried (Labconco Freeze zone $2.5)$ and left for 3 days. Finally, the extract was then diluted to $250 \mathrm{mg} / \mathrm{mL}$ using $10 \%$ Diamethyl Sulfoxide, DMSO as a solvent. The mixture was kept at $4^{\circ} \mathrm{C}$ until use.

For aqueous extraction, it was conducted using $1: 1 \mathrm{w} / \mathrm{v}$ ratio of $R$. tomentosa to distilled water. This ratio was used to allow full maceration of non-polar compounds out of this plant. Firstly, $200 \mathrm{~g}$ of powdered $R$. tomentosa was weighted and soaked into $200 \mathrm{~mL}$ distilled water and left agitated on an orbitary shaker for 24 hours. The next day, the solution is filtered using Whatmann filter paper. After that, it is transferred into a few conical tubes and kept at $-80^{\circ} \mathrm{C}$ freezer. It was then freeze- dried for 3 days. The dried extract is then diluted in, DMSO $10 \%$ solvent and kept at $4^{\circ} \mathrm{C}$ until used $^{10}$.

\section{Bacterial isolation and identification}

There were two bacterial stock culture used in this study. They were obtained from the Microbiology laboratory, Medical Laboratory Department, Faculty of Health Science, UiTM Puncak Alam. The bacterial strains that were involved were Staphylococcus aureus (ATCC 25923) and Escherichia coli (ATCC 25922). Identification of isolates was based on colony characteristics on Media culture such as, Nutrient agar, Blood agar, MacConkey agar, Eosin Methylene Blue agar, Triple Sugar Iron, Indole broth, Motility broth, Citrate agar, PD agar, DNase agar, Urease broth, Mueller 
Hinton broth and Methyl red-VP broth. Other identification test was Gram staining, catalase reaction, coagulase test and Dnase test. All bacterial that has been isolated were then cultured on Nutrient agar at $37^{\circ} \mathrm{C}$ for 18 to 24 hours.

\section{Antimicrobial sensitivity testing}

Disc diffusion test was selected for antimicrobial testing and performed according to recommendations and guidelines provided by the Clinical and Laboratory Standards Institute (CLSI $)^{11}$. The methanol and aqueous extract in DMSO solvent were used with the same concentration as a stock solution. The extract $(10 \mu \mathrm{L})$ from the $250 \mathrm{mg} / \mathrm{mL}$ stock solution was poured onto sterile filter paper disk with diameter of $6 \mathrm{~mm}$ by using a sterilw dropper. They were left dried in the oven at $40^{\circ} \mathrm{C}$ for 2 to 3 hour. Meanwhile, bacterial suspensions were prepared and adjusted to NO. $0.5 \mathrm{McFarland}$ turbidity standard. After incubation, the suspension was spread on Mueller-Hinton agar plates using sterile swab. Next, the discs were placed on the agar. Gentamycin $10 \mu \mathrm{g}$ and Penicillin $10 \mu \mathrm{g}$ were used as a positive control for $E$. coli and $S$. aureus, respectively. In this experiment, the negative control that was used is the DMSO solution. All of the tests were performed in triplicate with the same concentration of $R$. tomentosa leaves extract. The agar was then incubated at $37^{\circ} \mathrm{C}$ overnight. After measuring the growth inhibition zone, the isolates were categorized as sensitive or resistant as stated CLSI (2011) recommendations.

Determination of minimum inhibitory concentration (MIC)

The MIC concentration test was a test to determine the minimal concentration of extract to inhibit visible growth of bacteria after overnight incubation ${ }^{12}$. It was performed by the microdilution method on a microtiter plate. This process was done by adding plant extract and bacteria inoculum. In the 96-well microtiter plate, the first wellcontain initial concentration of extract which is $250 \mathrm{mg} / \mathrm{mL}$ of $R$. tomentosa. The extract $(20 \mu \mathrm{L})$ was added and two-fold serial dilution were performed to obtain final concentration ranging from 4 to $256 \mu \mathrm{g} / \mathrm{ml}$. Total volume was adjusted to $100 \mu \mathrm{L}$ by adding $80 \mu \mathrm{L}$ of Mueller Hinton Broth (MHB) in each well, followed by $100 \mu \mathrm{L}$ of the bacterial suspensions (106 CFU/mL). The culture plates were incubated for approximately 18 hours at $37^{\circ} \mathrm{C}$. Standard drug used in this test was the DMSO solution.

\section{Determination of minimum bactericidal} concentration (MBC)

$M B C$ was done after the MIC has been completed. This is due to the fact that $M B C$ is a test to confirm that there is no visible growth of bacteria. Thus, the test was done by streaking an aliquot of $0.1 \mathrm{~mL}$ from the clearest well in MIC until less clear well onto Nutrient agar. Next, the

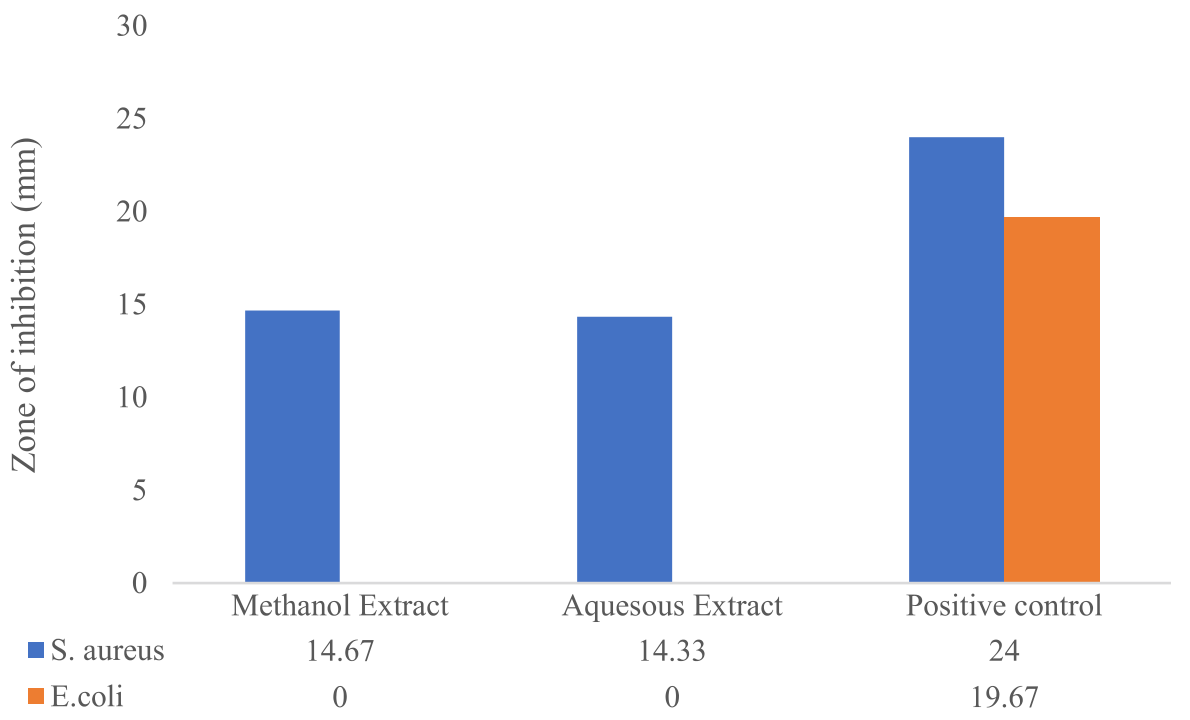

Fig. 1. Mean zone of inhibition against bacteria. 
agar was incubated at $37^{\circ} \mathrm{C}$ for 18 to 24 hours the agar plate was then observed for the growth of bacteria. It was then reported as growth or no growth.

\section{Statistical analysis}

Statistical analysis was done by conduct it through SPSS software program. It was first presented in a bar chart for the data collected (Fig. 1). Then, the result for $S$. aureus is obtained from finding its $p$-value. Statistically, a significant difference between the two bacteria was analyzed by using independent t-test. A result of $p$-value less than 0.05 was considered significantly different as one another.

\section{RESULT}

\section{Agar disc diffusion assay}

Table 1 and Table 2 showed the antibacterial activity of $R$. tomentosa methanolic extract tested by agar disk diffusion assay. The measured zone diameter compared with a standard chart for obtaining the susceptible and resistant values. Antibiotics used for susceptibility testing include Gentamycin10 $\mu$ g and Penicillin

Table 1. Staphylococcus aureus zone of inhibition

\begin{tabular}{lccc}
\hline Antibiotic & $\begin{array}{c}\text { Plate 1 } \\
(\mathrm{mm})\end{array}$ & $\begin{array}{c}\text { Plate 2 } \\
(\mathrm{mm})\end{array}$ & $\begin{array}{c}\text { Plate 3 } \\
(\mathrm{mm})\end{array}$ \\
\hline Methanol extract & 16 & 15 & 13 \\
Aqueous extract & 15 & 14 & 14 \\
Gentamycin 10 $\mu \mathrm{g}$ & 25 & 23 & 24 \\
DMSO $10 \mu \mathrm{l}$ & 0 & 0 & 0 \\
\hline
\end{tabular}

Table 2. Escherichia coli zone of inhibition

\begin{tabular}{lccc}
\hline Antibiotic & $\begin{array}{c}\text { Plate 1 } \\
(\mathrm{mm})\end{array}$ & $\begin{array}{c}\text { Plate 2 } \\
(\mathrm{mm})\end{array}$ & $\begin{array}{c}\text { Plate 3 } \\
(\mathrm{mm})\end{array}$ \\
\hline Methanol extract & 0 & 0 & 0 \\
Aqueous extract & 0 & 0 & 0 \\
Penicillin 10 & 20 & 20 & 19 \\
DMSO 10 & 0 & 0 & 0 \\
\hline
\end{tabular}

$10 \mu \mathrm{g}$ as a positive control. The methanolic extract at the concentration of $2.5 \mathrm{mg} /$ disk demonstrated intermediate antibacterial activity against Staphylococcus aureus (Table 1). It shows significant reaction towards all the drug and extract. While for E.coli, it only reacts significantly towards the commercial drug, but not to plant extract (Table 2). No significant differences were observed in inhibition zone diameter between methanol and aqueous of $R$. tomentosa against Staphylococcus aureus (Table 3).

\section{Determination of MIC}

The result of MIC for methanol against $S$. aureus shows it got clear well at $250 \mathrm{mg} / \mathrm{mL}, 125$ $\mathrm{mg} / \mathrm{mL}, 62.5 \mathrm{mg} / \mathrm{mL}$ and $31.25 \mathrm{mg} / \mathrm{mL}$. This means the MIC value for this extract against $S$. aureus start at $31.25 \mathrm{mg} / \mathrm{mL}$. The rest well, which are turbid means there is no inhibitory action on bacteria. Meanwhile, for aqueous extract, MIC for $S$. aureus start at $62.6 \mathrm{mg} / \mathrm{mL}$, not so much difference from methanol extract. It shows clear well from first until third well. The others were just turbid.

For Escherichia coli, the result of MIC for methanol extract against $E$. coli was begun at the third well which is $62.5 \mathrm{mg} / \mathrm{mL}$ onwards to 125 $\mathrm{mg} / \mathrm{mL}$ and $250 \mathrm{mg} / \mathrm{mL}$. Meanwhile, for aqueous extract, it only showed clear well at $250 \mathrm{mg} / \mathrm{mL}$ and $125 \mathrm{mg} / \mathrm{mL}$.

\section{Determination of $\mathrm{MBC}$}

For this study, the MBC test was done from all well from MIC microtiter plate so that confirmation can be made. The result was recorded as growth or no growth on Nutrient agar. $\mathrm{MBC}$ values ranged from $31.25 \mu \mathrm{g} / \mathrm{mL}$ to $250 \mu \mathrm{g} /$ $\mathrm{mL}$, against $E$. coli and $S$. aureus.

\section{DISCUSSION}

The ability of an extract to react toward the foodborne pathogen depending on the method of extraction and the types of solvent. The form of the extract is also an important consideration in determining the reaction of the

Table 3. P-value of the extract against Staphylococcus aureus

\begin{tabular}{|c|c|c|c|c|c|}
\hline Variable & $\begin{array}{l}\text { Aqueous }(n=3) \\
\text { Mean (SD) }\end{array}$ & $\begin{array}{c}\text { Methanol }(n=3) \\
\text { Mean (SD) }\end{array}$ & $\begin{array}{l}\text { Mean diff. } \\
(95 \% \mathrm{Cl})\end{array}$ & t-stats (df) & P-value \\
\hline $\begin{array}{l}\text { Zone of } \\
\text { inhibition }\end{array}$ & $\begin{array}{c}13.67 \\
(0.577)\end{array}$ & $\begin{array}{c}14.67 \\
(1.528)\end{array}$ & $\begin{array}{c}-1.00 \\
(-3.618 \\
1.618)\end{array}$ & $\begin{array}{c}-1.061 \\
(4)\end{array}$ & 0.349 \\
\hline
\end{tabular}


extract toward the bacteria. As per the previous studies, they have used ethanol and acetyl acetate as solvents because these two has low polarity index ${ }^{13}$. This present study used a different solvent which is methanol to decide which alcohol will yield this plant better. It also compared with water solvent as the purpose of this study was to find a safer natural-based-solvent to make preservatives. Although alcohol may be safe to consume declared by the Food and Drug Administration (FDA) but the repeated application might accumulate to something dangerous. This was applied to finding by the International Agency for Research on Cancer (IARC) stating alcohol as a Group 1 carcinogen (carcinogenic to humans) ${ }^{14}$.

Based on AST result, the methanol extract shows a slightly higher spectrum of antimicrobial activity compared to aqueous. Methanol extract is better in extraction as it has a lower polarity index than water so it is also able to pick up non-polar molecules. Meanwhile, water can be a good solvent for phytochemical extraction but only for the polar compounds. The choice of solvent depends upon the nature of compounds to be isolated ${ }^{15}$. As for this plant, it doesn't give that much significant change. This is referring to the mean zone of inhibition measured surround both methanol and aqueous extract against Staphylococcus aureus. It is noted that the diameter is differed by $2 \mathrm{~mm}$ only. In the antimicrobial test, $10 \mu$ l of Gentamycin and $10 \mu$ l Penicilin were used as a positive control for E.coli and S.aureus respectively. This finding is not comparable with the previous study as the study about an aqueous extract of $R$. tomentosa was still limited. After compared to AST parameter standard, the result obtained was intermediate (I) which means the concentration might be not high enough to inhibit the bacteria.

In addition, the previous study showed that the plant extract has significantly strong antimicrobial activity against $S$. aureus. The result may be different due to different strain of bacteria used which are Staphylococcus aureus (ATCC 29523). The importance of ATCC was to improve the breeding, preservation, classification and characterization of cultures and to develop new and enhanced culture products through in-house efforts and collaborative alliances. Besides, it was also maybe due to different solvent was used against these bacteria which is ethyl acetate ${ }^{13}$.
These contributions factors cause contradiction between the previous study and the present.

However, when it tested against Escherichia coli, the result gives a different impact. There was no zone of inhibition recorded at all from both methanol and aqueous extract. The result is in agreement with previous study stated that this plant works more significantly toward gram-positive bacteria ${ }^{16}$. According to Kone ${ }^{17}$, the study of various 50 medicinal plants reported no antibacterial activity against Escherichia coli and Pseudomonas. This is maybe due to the fact that gram-negative bacteria were more resistance compare to the gram-positive bacteria. In fact, the gram-negative bacteria consist of an extra outer membrane (cytoplasmic) after the thin peptidoglycan layer which doesn't exist on gram- positive bacteria. The presence of outer membrane contributes to the persistence of bacteria from being penetrated by the antibiotic. This outer membrane contains lipopolysaccharide which consists of lipid A, core polysaccharide and antigen $\mathrm{O}$.

The result from AST denotes to result of $\mathrm{MIC}$ and $\mathrm{MBC}$ because the same concentration of the extract was used for these two tests. Thus, the result is related to each other as confirmation. The MIC result of methanol extract against $S$. aureus clear well at well number 1 to 4 while $E$. coli got clear well from number 1 to 3 . This means that there is antimicrobial activity at that particular concentration of the methanol extract. Whereas, the result MIC for aqueous extract shows less clear well with $S$. aureus at the third well while $E$. coli only at the second well. Next, they were confirmed with the MBC. Result of MIC and MBC shows similarity as the purpose of $M B C$ is to confirm that there is no visible growth of bacteria. The MBC was done by taking the dilution made in MIC microtiter plate to be cultured again on Nutrient agar. Usually the only well that needs to be resubculture was from MIC until the highest concentration. After overnight, the result was recorded as growth or no growth of bacteria. However, in this study the MBC was done from every well of MIC for verification. As a result, at a particular concentration, there was no growth of bacteria on Nutrient agar.

From the result, some of the MBC was recorded compatible with MIC result while some of them didn't. MIC for methanol extract against 
S.aureus was at $31.25 \mathrm{mg} / \mathrm{ml}$ concentration and the $\mathrm{MBC}$ result shows no growth from $250 \mathrm{mg} / \mathrm{ml}$ until $31.25 \mathrm{mg} / \mathrm{ml}$. It is also the same with aqueous extract against $S$. aureus. Meanwhile, for E. coli, when methanol and aqueous extract did MIC test, it shows clear well until $62.5 \mathrm{mg} / \mathrm{ml}$ and $125 \mathrm{mg} /$ $\mathrm{ml}$, respectively but when tested $\mathrm{MBC}$, it shows the growth of bacteria from the second well $(125 \mathrm{mg} / \mathrm{ml})$ and onwards. Only total concentration shows the inhibitory action. This finding got quite similar result with the previous finding which got a different value of $\mathrm{MIC}$ and $\mathrm{MBC}^{18}$. This could be happened because of a too low concentration of stock extract used. It also explains why we need to make confirmation for MIC test. This means that even if a particular MIC shows inhibition, plating the bacteria onto agar might still result in organism proliferation because the antimicrobial did not cause death.

The test used in this study was independent T- test. It was done to compares the means between two unrelated groups on the same continuous and dependent variable. It is also to determine whether there is statistical evidence that the associated population means are significantly different. As for this study, independent $T$ test was used to compare the variables of the zone of inhibition between methanol and aqueous extract. The result obtained was $p>0.05$ which means not significant. Overall, there was no significant difference in the scores for methanol $(M=13.67, S D=0.577)$ and aqueous $(\mathrm{M}=14.67, \mathrm{SD}=1.528)$ conditions; $\mathrm{t}(4)=-1.061, \mathrm{p}$ $=0.349$ against $S$. aureus. These results suggest that methanol extract has not much different of strength in yielding than aqueous. Specifically, this result suggests that aqueous extract can also yield as strong as methanol in the role of antimicrobial agent.

\section{CONCLUSION}

As a conclusion, the present study achieved the main objective in determining the antimicrobial activities of Rhodomyrtus tomentosa. Both aqueous and methanol extract from $R$. tomentosa leaves, yielded similar antibacterial activity which susceptible to $S$. aureus and can be used safely toward foodborne pathogen. However, the extract was not strong enough to substitute with existing drug antibiotic. It is recommended in the future that this study is performed again but using a higher concentration of extract.

\section{ACKNOWLEDGMENTS}

We would like to express our deepest gratitude to Dr. Emida, Puan Azyana, Puan Norzila and other members of the Centre of Medical Laboratory Technology, Universiti Teknologi MARA (UiTM), Puncak Alam Campus for providing us with guidance and technical support. Furthermore, we also received generous support from Atta-urRahman Institute for natural Product Discovery (AuRins), Universiti Teknologi MARA (UiTM), Puncak Alam Campus.

\section{CONFLICT OF INTEREST}

The authors declare that there is no conflict of interest.

\section{AUTHORS' CONTRIBUTION}

All authors listed have made a substantial, direct and intellectual contribution to the work and approved it for publication.

\section{FUNDING}

This study was funded by the Fundamental Research Grant Scheme (FRGS) by the Ministry of Education Malaysia \{600-IRMI/FRGS/5/3 (196/2019)\}.

\section{DATA AVAILABILITY}

All datasets generated or analyzed during this study are included in the manuscript.

\section{ETHICS STATEMENT}

This article does not contain any studies relating to animal or human participants. It is solely performed by in-vitro assessment.

\section{REFERENCES}

1. Tang F, Saier MH. Transport proteins promoting Escherichia coli pathogenesis. Microbial Pathogenesis. 2014;71-72:41-55. doi: 10.1016/j.micpath.2014.03.008

2. Akinyemi $\mathrm{K}$, Oluwa $\mathrm{O}$, Omomigbehin $\mathrm{E}$. Antimicrobial activity of crude extracts of three medicinal plants used in South-West Nigerian folk medicine on some food borne bacterial pathogens. African Journal of Traditional, Complementary and Alternative Medicines. 2006;3(4). doi: 10.4314/ajtcam.v3i4.31173

3. Slutsker L, Alterkruse SF, Swerdloe DL. Food borne diseases: Emerging pathogens and trends. Infect Dis Clin North Am. 1998;12:199-216. doi: 10.1016/S0891- 


\section{0(05)70418-9}

4. Abdullah T, Abdullah N, Sinniah U. Genetic variation in Rhodomyrtus tomentosa (Kemunting) populations from Malaysia as revealed by inter-simple sequence repeat markers. Genetics and Molecular Research. 2015;14(4):16827-16839. doi: 10.4238/2015. December.14.10

5. Limsuwan S, Subhadhirasakul S, Voravuthikunchai SP. Medicinal plants with significant activity against important pathogenic bacteria. Pharm Biol. 2009;47(8):683-689. doi: $10.1080 / 13880200902930415$

6. Voravuthikunchai SP, Dolah S, Charernjiratrakul W. Control of Bacillus cereus in Foods by Rhodomyrtus tomentosa (Ait.) Hassk. Leaf Extract and Its Purified Compound. J Food Prot. 2010;73(10):1907-1912. doi: 10.4315/0362-028X-73.10.1907

7. Lai TN, Andre C, Rogez $\mathrm{H}$, et al. Nutritional composition and antioxidant properties of the sim fruit (Rhodomyrtus tomentosa). Food Chem. 2015;168:410416. doi: 10.1016/j.foodchem.2014.07.081

8. Hart J, Hamilton E J, Makepeace A, et al. Prevalence, risk factors and sequelae of Staphylococcus aureus carriage in diabetes: The Fremantle Diabetes Study Phase II. Journal of Diabetes and Its Complications. 2015;29(8):1092-1097. doi: 10.1016/j. jdiacomp.2015.06.005

9. Hoque M, Bari ML, Inatsu Y, et al. Antibacterial activity of guava (Psidium guajava L.) and neem (Azadirachta indica A. Juss.) extracts against foodborne pathogens and spoilage bacteria. Foodborne Pathogen and Disease. 2008;4:481-8. doi: 10.1089/fpd.2007.0040

10. Nagappan R. Evaluation of aqueous and ethanol extract of bioactive medicinal plant, Cassia didymobotrya (Fresenius) Irwin \& Barneby against immature stages of filarial vector, Culex quinquefasciatus Say (Diptera: Culicidae). Asian Pac J Trop Biomed. 2012;2(9):707711. doi: 10.1016/S2221-1691(12)60214-7
11. CLSI. Performance Standards for Antimicrobial Susceptibility Testing 21st ed. CLSI supplement M100. Wayne, PA: Clinical and Laboratory Standard Institute. 2011

12. Hamid HA, Zeyohannes SS, Yusoff, MM. Rhodomyrtus Tomentosa: A Phytochemical And Pharmacological Review. Asian J Pharm Clin Res. 2017;10(1):10-16. doi: 10.22159/ajpcr.2017.v10i1.12773

13. Sinulingga SE, Hasibuan PA, Suryanto D. Antibacterial Activity Of Karamunting (Rhodomyrtus Tomentosa (Aiton) Hassk) Leaf Extract And Fractions. Asian J Pharm Clin Res. 2018;11(3):163-165. doi: 10.22159/ ajpcr.2018.v11i3.23505

14. Pflaum T,Hausler T, Baumung C, Ackermann S, Kuballa T, Rehm J, Lachenmeier DW. Carcinogenic compounds in alcoholic beverages: an update. Arch Toxicol. 2016; 90(10):2349-2367. doi: 10.4238/2015.December.14.10

15. Monroy YM, Rodrigues RA, Sartoratto A, et al. Influence of ethanol, water, and their mixtures as co-solvents of the supercritical carbon dioxide in the extraction of phenolics from purple corn cob (Zea mays L.). The Journal of Supercritical Fluids. 2016;118:11-18. doi: 10.1016/j.supflu.2016.07.019

16. Limsuwan S, Trip EN, Kouwen TR, et al. Rhodomyrtone: A new candidate as natural antibacterial drug from Rhodomyrtus tomentosa. Phytomedicine. 2009;16(67):645-651. doi: 10.1016/j.phymed.2009.01.010

17. Kone WM, Atindehou KK, Terreaux C, Hostettmann K, Traore D, Dosso M. Traditional medicine in North Cote-d'Ivoire: Screening of 50 medicinal plants for antibacterial activity. J Ethnopharmacol. 2004;93(1):4349. doi: 10.1016/S0378-8741(04)00108-4

18. Vo T, Ngo D. The Health Beneficial Properties of Rhodomyrtus tomentosa as Potential Functional Food. Biomolecules. 2019;9(2):76. doi: 10.3390/ biom 9020076 